\title{
Evaluation of Serum Level of Soluble Suppressor Tumourginicity 2 (sST2) in Pregnancies Complicated by Preeclampsia \\ N.A.Abdel Hafeez ${ }^{1}$, O.S.El-Shimi ${ }^{1}$, H.E.Raziq ${ }^{2}$ and M.Y.Mikhael ${ }^{1}$ \\ ${ }^{1}$ Clinical \& Chemical Pathology Dept., Faculty of Medicine, Benha Univ., Benha, Egypt \\ ${ }^{2}$ Gynecology \& Obstetrics Dept., Faculty of Medicine, Benha Univ., Benha, Egypt \\ E-Mail:Mina@gmail.com
}

\begin{abstract}
Toxemia (PE) is characterized as new-beginning hypertension and proteinuria or opposite end-organ harm (counting hepatic, renal, hematological, or neurological intricacies) happening following 20 weeks of pregnancy or fetal development limitation. Point and goals : The point of this investigation was to evaluate the serum level of solvent silencer tumorginicty 2 (sST2) in pregnant ladies convoluted with toxemia contrasting and evidently solid pregnant ladies. Techniques: Eighty ladies took care of Benha University Hospitals were isolated into two gatherings; Group (I): Fourty toxemia tolerant, Group (II): Fourty solid subjects as control. Results: Serum sST2 was essentially higher in toxemia cases instead of the obviously solid pregnant controls $(\mathrm{P}<0.001)$. End : sST2 might be helpful in conclusion of ladies compilicated by toxemia.
\end{abstract}

Keywords : Preeclampsia (PE), Soluble suppressor tumourginicity 2 (sST2) .

\section{Introduction}

Toxemia (PE) is characterized as new-beginning hypertension and proteinuria or opposite end-organ harm (counting hepatic, renal, hematological, or neurological complexities) happening following 20 weeks of pregnancy or fetal development limitation [1].

Toxemia is generally analyzed by new-beginning hypertension and proteinuria at $\geq 20$ long stretches of growth [2].

Proteinuria of more prominent than or equivalent to 0.3 grams in a 24-hour pee example, a protein $(\mathrm{mg} / \mathrm{dL}) /$ creatinine $(\mathrm{mg} / \mathrm{dL})$ proportion of 0.3 or higher, or a pee dipstick protein of 1+ (if a quantitative estimation is inaccessible) is needed to analyze toxemia [3].

Silencer of tumorigenicity 2 (ST2) is an individual from the interleukin-1 receptor (IL-1R) family and, along with its ligand IL-33, are related with a Th2 resistant reaction through the creation of mitigating cytokines, for example, IL-4, IL-5, and IL-13 [4].

The ST2 receptors include a layer secured receptor (ST2L) and a dissolvable ST2 (sST2) receptor that go about as fakes for IL-33 [5].

This receptor is emitted by endothelial cells during inflammation[6].

Solvent ST2 fixations are expanded in the third trimester of ordinary pregnancy and, along with IL-33 and ST2L, may assume a significant part in keeping up the immunoregulation of typical pregnancy [7].

\section{Study subjects}

This examination was completed on females alluded to Gynecology and Obstetrics division and outpatient center, Benha University Hospitals. Lab examinations were done in Clinical and Chemical Pathology division, Benha University Hospitals. The current examination included 80 pregnant females of coordinated age and gestational age. They were arranged into 2 gatherings
Understanding gathering: included 40 pregnant ladies determined to have toxemia (PE).control gathering: included 40 females with typical pregnancy.

Incorporation measures: All patients were remembered for the investigation if toxemia was analyzed following 20 weeks of incubation, as per the accompanying rules Blood pressure higher than 140/90 $\mathrm{mmHg}$ at 2 separate events, 4 hours separated. Or then again Blood pressure higher than or equivalent to $160 / 110 \mathrm{mmHg}$, Along with huge proteinuria $\geq 300$ $\mathrm{mg} / \mathrm{L}$ in a $24-$ hour pee assortment or a dipstick perusing of $\geq 1+$ on a voided irregular pee test without urinary lot contamination. [8]

Avoidance measures: Any subject was prohibited from the investigation, on the off chance that she had: Eclampsia, HELLP condition, Gestational diabetes mellitus, Clinical chorioamnionitis, threat or any irresistible problems, urinary parcel contamination (UTI) or some other reason for proteinuria.

This examination was acted in understanding to the moral rules of the 2004 Declaration of Helsinki. The investigation convention was endorsed by the neighborhood morals board of trustees on research including human subjects of Faculty of Medicine, Benha University. Educated assents were gotten from all members preceding their enlistment in the examination.

\section{Techniques}

All enlisted subjects were assessed by: Full history: including: Present history: name, age, weight, long stretches of incubation, primigravida or multigravida .Obstetric history: of unsuccessful labor and toxemia. Family background: of pregnancy actuated hypertension and toxemia.

Research center Investigations :During the antenatal consideration; tests were acquired from all contemplated subjects to recognize: Liver capacity tests (ALT, AST, egg whites), Complete blood picture, 
Proteinuria, Serum dissolvable silencer tumourginicity 2 (sST2) level.

\section{Measurable investigation}

Information were taken care of to the PC and dissected utilizing IBM SPSS programming bundle rendition 20.0 (Armonk, NY: IBM Corp). Subjective information were portrayed utilizing number and percent. Quantitative information were depicted utilizing mean \pm standard deviation (SD). Importance of the acquired outcomes was acknowledged at $\mathrm{P}$ esteem 0.05 with $95 \%$ certainty span (CI). Chi-square test: for unmitigated factors, to think about between various gatherings.

\section{Results}

A case-control study conducted on 80 pregnant female patient attending to Gynecology and Obstetrics department and outpatient clinic, Benha University Hospitals. Fourty preecalmpsia (group I) and fourty apparently healthy subjects as control (group II) .

Table (1) Comparison of blood pressure between the studied groups. Both systolic and diastolic blood pressure were significantly higher in preeclampsia cases compared to the apparently normal pregnant females ( $\mathrm{P}<0.001$ each).

Table (2) Distribution of the studied preeclampsia cases according to severity. Twenty two $(55 \%)$ of preeclampsia cases had mild, 8 patients $(20 \%)$ had moderate and $10(25 \%)$ of patients had severe disease.

Table (3) Comparison of the relevant laboratory data between the studied groups.

Table (1) Comparison of blood pressure between the studied groups.

\begin{tabular}{lcccc}
\hline $\begin{array}{l}\text { Blood pressure } \\
(\mathbf{m m H g})\end{array}$ & $\begin{array}{c}\text { Preeclampsia } \\
(\mathbf{n}=\mathbf{4 0})\end{array}$ & $\begin{array}{c}\text { Normal pregnancy } \\
(\mathbf{n}=\mathbf{4 0})\end{array}$ & $\mathbf{T}$ & $\mathbf{P}$ \\
\hline $\begin{array}{l}\text { Systolic } \\
\text { Mean } \pm \text { SD }\end{array}$ & $159.25 \pm 9.17$ & $105.75 \pm 12.33$ & 22.024 & $<0.001$ \\
$\begin{array}{l}\text { Diastolic } \\
\text { Mean } \pm \text { SD }\end{array}$ & $103.25 \pm 6.16$ & $70.0 \pm 8.77$ & 19.626 & $<0.001$ \\
\hline
\end{tabular}

t: Student t-test.

Table (2) Distribution of the studied preeclampsia cases according to severity $(n=40)$.

\begin{tabular}{lcc}
\hline Severity & No. & $\%$ \\
\hline Mild & 22 & 55.0 \\
Moderate & 8 & 20.0 \\
Severe & 10 & 25.0 \\
\hline
\end{tabular}

Table (3) Comparison of the relevant laboratory data between the studied groups.

\begin{tabular}{|c|c|c|c|c|c|c|}
\hline & \multicolumn{2}{|c|}{$\begin{array}{l}\text { Preeclampsia } \\
\quad(n=40)\end{array}$} & \multicolumn{2}{|c|}{$\begin{array}{c}\text { Normal pregnancy } \\
(\mathrm{n}=\mathbf{4 0})\end{array}$} & Test & $\mathbf{P}$ \\
\hline Platelets (x10`9/L) & \multirow{2}{*}{\multicolumn{2}{|c|}{$163(113.5-260.0)$}} & \multirow{2}{*}{\multicolumn{2}{|c|}{$207(150.0-289.5)$}} & $\mathrm{U}=581.0$ & 0.035 \\
\hline Median (IQR) & & & & & $\mathrm{U}=581.0$ & 0.035 \\
\hline $\begin{array}{l}\text { SGOT (U/L) } \\
\text { Median (IQR) }\end{array}$ & \multicolumn{2}{|c|}{$23(20-35)$} & \multicolumn{2}{|c|}{$29(23-31)$} & $\mathrm{U}=629.0$ & 0.099 \\
\hline $\begin{array}{l}\text { SGPT (U/L) } \\
\text { Median (IQR) }\end{array}$ & \multicolumn{2}{|c|}{$19(16-29.5)$} & \multicolumn{2}{|c|}{$28.5(25-31.5)$} & $\mathrm{U}=475.0$ & 0.002 \\
\hline $\begin{array}{l}\text { Albumin }(g / d l) \\
\text { Mean } \pm \text { SD }\end{array}$ & \multicolumn{2}{|c|}{$3.65 \pm 0.61$} & \multicolumn{2}{|c|}{$4.03 \pm 0.25$} & $\mathrm{t}=3.568$ & 0.001 \\
\hline Proteinuria & No. & $\%$ & No. & $\%$ & & \\
\hline Nil & 7 & 17.5 & 34 & 85.0 & & \\
\hline Trace & 15 & 37.5 & 4 & 10.0 & $\chi^{2}=$ & \\
\hline+ & 6 & 15.0 & 2 & 5.0 & 39.86 & $<0.001$ \\
\hline ++ & 10 & 25.0 & 0 & 0.0 & & \\
\hline+++ & 2 & 5.0 & 0 & 0.0 & & \\
\hline
\end{tabular}

U: Mann Whitney test, t: Student t-test, $\chi^{2}$ : Chi square test.

\section{Discussion}

The point of this examination was to survey the serum level of solvent silencer tumorginicty 2 (sST2) in pregnant ladies convoluted with toxemia contrasting and obviously sound pregnant ladies so as to assess its part being developed of toxemia and its connection with infection seriousness. 
To understand the focused on point, this investigation was directed on 40 patients with toxemia and 40 clearly solid pregnant as control gathering.

All patients and controls were exposed to full history taking and clinical assessment. Research facility examinations remembered protein for pee, liver capacity tests [serum egg whites, AST and ALT], complete blood check and seum sST2 level.

In current investigation, both systolic and diastolic circulatory strain were altogether higher in toxemia cases contrasted with the evidently ordinary pregnant females ( $\mathrm{P}<0.001$ each). [9] , [10] as very much showed a measurably critical higher in systolic and diastolic pulse in toxemia patients more than in control gathering $(\mathrm{P}<0.001) \quad[9,10]$.

As to most toxemia applicable research facility information we found that in spite of the fact that platelets include in the contemplated bunches were inside ordinary reach, it was essentially lower in toxemia cases than typical pregnant controls ( $\mathrm{P} 0.035)$. This comes in accordance with [11], [12] who exhibited an essentially lower platelet include in patients with toxemia contrasted and the typical controls.[11],[12] On another side, [10] indicated that platelet include was in ordinary reach in this contemplated gatherings and there was no critical chang in platelet check between toxemia cases and typical pregnancy cases [10].

At the point when we assessed the liver capacity [SGOT,SGPT and serum albumin] in totally contemplated subjects, we discovered them inside ordinary range.SGPT was essentially lower in toxemia cases than typical pregnant controls (P 0.002). On the opposite [13] demonstrated that ladies with toxemia had measurably huge higher estimations of SGOT and SGPT contrasted and sound pregnant women [13]. We discovered serum egg whites in toxemia cases was altogether lower than in the clearly ordinary pregnant controls. Like [14].

Various levels of proteinuria were altogether found in toxemia cases more than in the clearly ordinary pregnant controls $(\mathrm{P}<0.001)$. These results were in simultaneousness with[15], [9],[10]who detailed that proteinuria were altogether found in toxemia cases more than in the clearly typical pregnant controls $[15$, $9,10]$.

Our investigation uncovered that serum sST2 was essentially higher in toxemia cases instead of evidently sound pregnant controls.

At last we can reason that $\mathrm{SST} 2$ has a decent analytic incentive in conclusion of toxemia.

\section{Reference}

[1] A.L.Tranquilli, G.Dekker, L. Magee.The classification, diagnosis and management of the hypertensive disorders of pregnancy: A revised statement from the ISSHP. Pregnancy Hypertens, Vol.4(2), PP.97-104. 2014.

[2] A.K.Singh, G.H.Williams.Soluble adhesion molecule profile in normal pregnancy and pre- eclampsia. J Matern Fetal Neonatal Med,Vol.12(1),PP.19-27. 2017

[3] K.H.Lim. Preeclampsia. Medscape. Updated: Sep 15 2016. Http://emedicine.medscape.com/article/1476919overview. Accessed 1-4-2016

[4] M.Peine, R.M.Marek, M. Löhning, IL-33 in T Cell Differentiation, Function, and Immune Homeostasis. TRENDS IMMUNOL,Vol.37(5),PP.321-333,2016.

[5] G.Palmer, C.Gabay. Interleukin-33 biology with potential insights into human diseases. Nat Rev Rheumatol,Vol.7(6),PP.321-329, 2011.

[6] V.Topping, R.Romero, N.G.Than. Interleukin-33 in the human placenta. J Matern Fetal Neonatal Med,Vol. 26(4),PP.327-38,2012.

[7] T.Stampalija, T.Chaiworapongsa, R.Romero, Soluble ST2, a modulator of the inflammatory response, in preterm and term labor. Journal for $\mathbf{J}$ MATERN-FETAL NEO M,VOL.27,PP.111$121,2014$.

[8] J.M.Roberts, P.A.August, G.Bakris. Hypertension in pregnancy. Report of the American College of Obstetricians and Gynecologists' Task Force on Hypertension in Pregnancy. Obstetric Gynecology,Vol.122(5),PP. 1122-31,2013.

[9] I.Granne, J.H.Southcombe, J.V.Snider, ST2 and IL-33 in pregnancy and pre-eclampsia. PLoS.2011; doi: 10.1371/journal.pone.0024463.

[10] T.Stampalija, T.Chaiworapongsa, R.Romero, Maternal plasma concentrations of $\mathrm{sST} 2$ and angiogenic/anti-angiogenic factors in preeclampsia. J Matern Fetal Neonatal Med,Vol.26 (14),PP.1359-1370, 2013.

[11] M.A.AlSheeha, R.S.Alaboudi, M.A.Alghasham, Platelet count and platelet indices in women with preeclampsia. Vasc Health Risk Manag,Vol.12,PP.477-480,2016.

[12]N.Thalor, K.Singh, M.Pujani, A correlation between platelet indices and preeclampsia. Hematol Transfus Cell Ther,Vol.41(2),PP.129-133, 2019.

[13]R.Dacaj, S.Izetbegovic, G.Stojkanovic, S.Dreshaj.Elevated Liver Enzymes in Cases of Preeclampsia and Intrauterine Growth Restriction. Med Arch,Vol.70 (1),PP.44-47,2016.

[14] S.Won-Joon, .Gun-Oh, H.Dae-Gy, Clinical significance of serum albumin level in pregnancyrelated hypertension.J Obest Gyncol Res.,Vol.36,(6),PP. 1165-1173.2010.

[15] R.Romero, P. Chaemsaithong, T. Chaiworapongsa. Maternal plasma soluble ST2 concentrations are elevated prior to the development of early and late onset preeclampsia.J Matern Fetal Neonatal Med,Vol.31(4),PP.418-432,2018. 